\title{
FARMLAND REAL ESTATE INVESTMENT TRUSTS
}

\author{
Miljan Leković ${ }^{1}$, Drago Cvijanović ${ }^{2}$, Milena Jakšić ${ }^{3}$ \\ *Corresponding authorE-mail:m.lekovic@kg.ac.rs
}

\begin{abstract}
A R T I C LE IN F O
A B S T R A C T

Review Article

The modern era has brought the need for the establishment

Received: 28 February 2018 of farmland real estate investment trusts. The establishment

Accepted: 07 May 2018 of these trusts positively affects growth and development of agricultural sector and ultimately contributes to global doi:10.5937/ekoPolj1802745L

UDC 631.48:330.332 poverty reduction and sustainable development of the world economy and society. The research objective is to highlight the importance of these institutional investors as a new mechanism for investing in farmland and an

Keywords:

real estate investment trusts, farmland, F-REITs

JEL: G23, Q14, R30 additional source of financing for the agricultural sector. No studies on this issue in domestic and insufficient number of them in foreign literature have been a motive for the conducted research. The intention is to introduce investment community with the basic characteristics of farmland real estate investment trusts, as well as the key factors that arouse interest and lead to investment in farmland as new asset class.
\end{abstract}

(C) 2018 EA. All rights reserved.

\section{Introduction}

Wealthy individuals' investment in farmland goes back into the distant past, while significant investment by institutional investors in this type of assets was recorded at a time of rapid growth in its value of the 1970s. Stagnation of demand that followed in the early 1980s led first to a decline in the price of agricultural products, and subsequently to a consequent decline in the value of farmland. Relevant studies describe this situation as farm crisis. Nevertheless, in late 1980s, investors' interest in farmland and farm facilities was renewed, and, according to Koeninger (2017), one of the factors that significantly contributed to their renewed interest was the article "Buy a Farm and Get Rich Slowly" by Barton Biggs, published in January 1988.

1 Miljan Leković, Ph.D., Assistant Professor, University of Kragujevac, Faculty of Hotel Management and Tourism in Vrnjačka Banja, Vojvođanska Street no. 5A, 36210 Vrnjačka Banja, Serbia, Phone: +381 6435823 04, E-mail: m.lekovic@kg.ac.rs, ORCID ID https:// orcid.org/0000-0002-4952-3991

2 Drago Cvijanović, Ph.D., Full Professor, University of Kragujevac, Faculty of Hotel Management and Tourism in Vrnjačka Banja, Vojvođanska Street no. 5A, 36210 Vrnjačka Banja, Serbia, Phone: +381 63295 111, E-mail: drago.cvijanovic@kg.ac.rs, ORCID ID https://orcid.org/0000-0002-4037-327X

3 Milena Jakšić, Ph.D., Full Professor, University of Kragujevac, Faculty of Economics, Đure Pucara Starog Street no. 3, 34000 Kragujevac, Serbia, Phone: +381 6531507 00, E-mail: milenaj@kg.ac.rs, ORCID ID https://orcid.org/0000-0003-0553-6085 
The period to come was marked by significant investment of pension funds in farmland, where one of the main investment motives was the intention to improve the effects of diversification of investment given low and often negative correlation between farmland return and return on financial assets. In an effort to accept farmland as a new asset class, the National Council of Real Estate Investment Fiduciaries (NCREIF) Farmland Index was introduced in 1995, on the basis of pre-existing stock and bond indices. In this way, institutional investors got the opportunity and ability to assess farm, i.e. farmland managers' performance, by comparing the achieved return with the average market return, calculated on the basis of the NCREIF Farmland Index.

At the beginning of the 21st century, the growing demand for food, caused primarily by rapid growth of the world population and the growth of the purchasing power of population in developing countries, resulted in increased investment in farmland by individual and institutional investors. The demand for farmland increased especially during and after the global financial and economic crisis of late 2007, due to investors' search for a safer and alternative asset class. A few years later, in response to the growing demand for farmland, farmland real estate investment trusts (F-REITs) emerged.

F-REITs are a new type of farmland and farm facilities real estate investment trusts. Studies dealing with F-REITs are scarce even in the most developed world countries, which is not surprising given the short history of these trusts. The motive for the conducted research lies in an intention to at least partially mitigate the lack of relevant literature in this field.

Bearing in mind the foregoing, the research subject is F-REITs, as new farmland investment vehicles. The research objective is to introduce the investment community with the basic characteristics of this new category of farmland real estate investment trusts.

With reference to the defined research subject and objective, the paper will, after the introductory remarks and review of the relevant literature, analyze the importance of farmland as a new and attractive asset class. The emergence and development of the first world F-REITs will then be described. After that, the concept of functioning of these institutional investors will be presented, with inevitable indication of the key advantages and disadvantages of investing free cash in F-REITs in relation to direct purchase of farmland. Finally, the final part of the paper will summarize the views presented and consider opened questions of importance for future research.

\section{Review of literature}

Determining the real benefits of including farmland in investment portfolio is an issue that has aroused considerable interest of economists in the past decades. Numerous studies support the claim that the inclusion of farmland in the portfolio enhances its performance (Lins et al., 1992; Hennings et al., 2005; Painter, 2013a and others). Lins et al. (1992) and Hennings et al. (2005) found that farmland return is positively correlated with inflation and low or negatively correlated with return on stocks and bonds, so the inclusion of farmland into the portfolio brings protection from inflation, on the 
one hand, and, on the other hand, increases the benefits of diversification. According to Kaplan (1985), farmland is a powerful inflation hedge, because, compared to other asset classes, it has the highest return correlation with the Consumer Price Index (CPI). In the study, the correlation coefficient between farmland return and CPI is 0.663 , while the correlation coefficient between return of other asset classes and CPI is negative, except in the case of T-bills. The authors agree that extra return, resulting from the inclusion of farmland in the portfolio, is higher than additional risk, because, given the low correlation between farmland return and return on traditional assets, most of the additional risk is eliminated by diversification.

Given the above, but also stable long-term benefits that farmland investment promises, it is not difficult to conclude why farmland is for investors a serious candidate to improve portfolio performance. According to Robaton (2015), in the last 20 years farmland has had impressive returns as an asset class, outperforming major real estate sectors and most other types of investments. Between 1995 and 2013, the NCREIF Farmland Index had an average annual return of slightly more than 12 percent, while NCREIF's Commercial Property Index and Standard \& Poor's 500 (S\&P 500) index each had annualized return of about 9 percent.

The results of the research conducted by Painter (2013a) also highlight competitive farmland return. Assessing the North American farmland investment performance using the Capital Asset Pricing Model (CAPM), the Expected Value-Variance Model (E-V Analysis), and the Value at Risk Model (VAR), the author finds that the growing demand for farmland investment is due to the fact that farmland investment yield is very competitive with stocks, bonds etc., and the inclusion of farmland and portfolio enhances the effects of diversification, thereby improving overall investment performance.

Johnson et al. (2006) also examines the effects of inclusion of agribusiness assets in investment portfolios, to conclude that agribusiness return exhibits low correlation with return on stocks (coefficient of correlation being 0.48 ) and return on property (correlation coefficient being 0.23 ), and negative correlation with return on bonds (correlation coefficient being -0.06). Low and negative correlation confirms the previously stated claim that inclusion of agribusiness assets in investment portfolios improves the effects of diversification and brings benefits in the form of reduced investment risk. Some authors, such as Nartea and Eves (2010), believe that the benefits of inclusion of farmland in portfolio composed of traditional assets are reflected more in reducing risk than in improving return.

De Laperouse (2016) also points to low correlation between returns on farmland investments and the broader markets, and the consequent risk reduction potential. The author points out that, over the past 10 years, the correlation of the quarterly returns on the NCREIF with the Dow Jones Industrial Average (DJIA) has been $0.101 \%$ and with the S\&P 500 it has been $0.098 \%$. De Laperouse (2016) adds that farmland should not be understood as homogeneous but as a heterogeneous asset class, because of different geographical areas (Asia, Australia, South America, etc.), different types of production 
(permanent crops, dairy, aquaculture, etc.), and different operating models (land ownership, farm management, value chain investment, etc.) available to investors, which provides an opportunity for intra-asset class diversification.

Pointing to the importance of investment diversification as an investment strategy to reduce investment risk, Coleman (2007) points out that the first step in building an agricultural investment portfolio is to identify regions where rainfall is uncorrelated and sectors where commodity prices are uncorrelated. In this way, protection against both drought and floods and the excessive volatility of commodity prices is achieved. It should also be noted that Coleman (2007) lists rainfall and commodity prices, and farm management and asset appreciation, as the most important factors of return on agriculture investment.

Among the available studies, the comparative analysis of farmland with gold and oil, given by Painter (2013b), is also worthy of attention. The author finds that all three asset classes have low correlation with stocks, bonds, T-bills, and other traditional asset classes, and that all three asset classes provide protection against inflation. However, the key advantage of farmland in relation to gold and oil is reflected in the fact that farmland provides better protection against inflation given higher positive correlation with CPI, and that, unlike gold and oil, generates revenue, which is why financial literature popularly refers to it as "gold with yield". Owners of gold and oil are in a position to make profit based on the movement of prices of these assets, while owners of farmland, in addition to the movement of prices, have the opportunity to earn profit by organizing production on farmland, leasing land, etc. The potential profit brought by gold and oil is, due to the higher volatility of their prices, higher than income farmland promises, but, according to Painter (2013b), risk is three times higher. In the same paper, the author points out that, owing to the high positive correlation between farmland, gold and oil, the stated asset classes may be interchangeable as diversifying agents in portfolios.

\section{Farmland as a new asset class}

One of the most important steps in accepting farmland as a new asset class was the introduction of the NCREIF Farmland Index in 1995. NCREIF Farmland Index describes the overall trends on the farmland market in the U.S. and represents the basis for determining the average market return. It compares the average market return and returns of individual portfolios comprised of farmland, and the comparison is, as a rule, done on a risk-weighted basis. In this way, portfolio managers, individual and institutional investors find out if the created portfolio has achieved superior, average, or inferior performance compared to the market.

Farmland is currently experiencing an investment renaissance of a kind not seen in the United States since at least the 1970s and globally perhaps ever (Fairbairn, 2014). The key factors that generate investors' interest and the resulting investment in farmland as a new asset class are: 
- Improving portfolio performance,

- Attractive and stable return with relatively low investment risk,

- Negative correlation between farmland return and return on traditional asset classes (stocks, bonds, etc.), which gives investors the possibility of efficient diversification of investment,

- Positive correlation between farmland return and CPI, which provides investors with protection against inflation,

- The rising demand for food as a result of the rising global population, longer life expectancy, and rising living standards and purchasing power of the population,

- Reduced food supply as a result of rising urbanization, accelerated land degradation, and climate change,

- Increased global demand for biofuel as renewable energy source obtained by biomass processing,

- Threatened global food security.

The above group of factors can be extended by the fact that farmland is less impacted by economic recessions, as demand for food is relatively inelastic to income. Also, one of the motives for investing free cash in farmland lies in the fact that the supply of farmland is limited, the possibilities for its growth are limited, while at the same time the demand for farmland for the previously described reasons is constantly increasing. Limited supply of farmland and, at the same time, rising demand for water increase the prices of farmland and investors' profitability.

It should also be noted that periods of financial crises, such as the crisis of early $2000 \mathrm{~s}$ that hit the most developed world countries, and the financial and economic crisis of 2007-2009 that had a negative impact on the entire world market, are characterized by the spillover of cash from the market of stocks, bonds, and other traditional financial instruments into the markets of real assets, such as the farmland market. The main reason for the spillover of funds from the traditional financial instruments market to the farmland market is reflected in the fact that farmland, unlike securities, has a real value that is not subject to large fluctuations. Possession of farmland in a portfolio during a period of financial crises brings increased wealth protection.

All the aforementioned and explained factors make farmland an attractive asset class both for individual and institutional investors, and pave the way for its acceptance and inclusion in a diversified portfolio.

\section{The emergence and development of F-REITs}

Farm owners have always sought to consolidate agricultural holdings in order to realize the benefits of economies of scale and increase their profit. Also, they strove to procure 
modern techniques and technology to increase labor productivity, efficiency of labor resources and technical equipment. Lack of funds forced farmers to take expensive loans from banks that increase the financial risk of a farm business and take the land for lease and pay cash or share leases. This created the need to establish F-REITs as institutions specialized in investing in farmland and farm facilities, which, from the perspective of farm owners, represent a cheaper and less risky source of financing.

Prior to the establishment of F-REITs, a large number of institutional investors, such as private equity funds, pension funds, hedge funds and sovereign wealth funds, were investing in agriculture and farmland. However, the key advantage of F-REITs in relation to the previously listed institutional investors is reflected in the fact that F-REITs are exempt from corporate income tax. In this way, they can avoid double taxation (taxation at the trust level and taxation at the individual investor level), which, from investors' perspective, equates tax costs between direct and indirect investment in real estate.

Investors' interest in farmland increased especially during the 2007-2008 world food price crisis. Some of the factors that led to the rise in the price of food commodities are the rise in oil price on the world market and the consequent increase in the cost of production of agricultural products, as well as the response of individual governments to the increased oil price by supporting the production of biofuel as a renewable energy source, obtained by biomass processing. The growth of food prices increased world hunger and had a negative impact on global food security, but at the same time had a positive impact on the growth of public and private investment in the agricultural sector. Public investment was undertaken with the aim of achieving food security, which is at the top of the list of sustainable global development priorities (Đurić, Njegovan, 2016), while private investment in the agricultural sector was realized to achieve profit.

In addition to food price crises, global financial and economic crisis of late 2007 also had a dual effect: on the one hand, it made it difficult to do business and reduced the availability of financial resources, while, on the other hand, it encouraged investment in the agricultural sector, primarily in farmland, given its resistance to crisis impacts. Increased investment in farmland is a consequence of investors' search for a safer and alternative asset class, which, owing to a negative correlation with traditional asset classes, improves the effects of diversification. The attractiveness of the agricultural sector in the crisis period is explained by the fact that the demand for food is inelastic.

Growing investment in farmland as a safer and alternative investment option continued even after the crisis years, resulting in the emergence ofF-REITs - investment mechanisms specialized for investment in farmland. The first company that received the status of F-REIT is Gladstone Land (NASDAQ ticker symbol LAND). On 1 January 2013, the company made the initial public offering (IPO), and in the autumn of the same year it was declared F-REIT. On 31 December 2016, the company owned 58 farms comprised of 50,592 total acres, valued at approximately \$ 401 million (Gladstone Land, 2016).

A year later, F-REIT status was granted to the Farmland Partners (NYSE ticker symbol FPI), which in April 2014 made an IPO and thus became the second REIT in history 
specialized for investing in farmland. On 31 December 2016, Farmland Partners had 115,489 acres of land in its portfolio (Farmland Partners, 2016).

The third established F-REIT is the American Farmland Company (NYSE ticker symbol AFCO). In October 2015, the company made an initial public offering and acquired the status of F-REIT. On 30 June 2016, American Farmland's portfolio comprised 22 properties with more than 18,322 acres that stretch across 13 states throughout the United States with 21 different crops (FBR \& Co, 2016).

Half a year later, on 2 February 2017, Farmland Partners merged with American Farmland Company to form the largest F-REIT in the United States, which retained the Farmland Partners name and the ticker symbol FPI. The continuing growth and development of this F-REIT is best illustrated by the fact that since the IPO of April 2014 through August 2017, the portfolio owned by this trust rose 20 times, more specifically, from 7,300 acres to 154,000 acres - to be honest, in good part thanks to the merger.

\section{The concept of functioning of F-REITs}

F-REITs combine individual investors' funds, and then invest them in farmland, thereby gaining numerous advantages for their shareholders, such as providing professional portfolio management services, reducing investment risk through diversification of investment, reducing transaction costs by achieving economies of scale, etc. In addition to the foregoing, F-REITs provide their shareholders with:

- Higher liquidity of investment - stems from the possibility of relatively fast sale of these trusts' shares on the stock market, unlike farmland, whose sale requires time,

- Cheap diversification of investment - by purchasing one stock of the trust, the investor indirectly becomes the co-owner of the efficiently diversified assets of the trust,

- Greater security of investment - security has always been a feature of real estate investment, and has been further enhanced through effective diversification of investment.

Broad community can invest in F-REITs, as new farmland investment vehicles, regardless of the level of knowledge and the level of available capital. The establishment of F-REITs allows for small investors' participation on the farmland market with a modest amount of free cash.

The emergence of F-REITs has enabled the division of farmland as an asset class, which was previously unthinkable as land worth thousands or millions of dollars was sold in its entirety. Today, by purchasing one stock of F-REITs, minor percentage ownership is realized in a large number of agricultural parcels. 
Investors in F-REITs expect stable long-term returns, with simultaneous protection against inflation, achieved thanks to a positive correlation of farmland returns with inflation. Investors in F-REITs also count on effective diversification of investment given low correlation between farmland returns and return on stocks, bonds, and other traditional classes of assets.

F-REITs do not promise investors quick, but steady growth in stock values with regular dividend payments. Regular payment of dividends to shareholders, or at least $90 \%$ of revenue generated, is a precondition that must be met in order for these trusts to retain the status of real estate trusts and enjoy tax exemptions. It is not difficult to conclude that investing in F-REITs suits more conservative investors with a low level of risk tolerance. At the same time, aggressive investors want to get richer as soon as possible, and invest in investment trusts with a more risky investment strategy and investment policy.

In order to maximize earnings, F-REITs look for underestimated farmland, which farmers are forced to sell due to financial difficulties. A good opportunity to earn is also the purchase of inherited farmland from families that do not want this type of asset and want to sell it as soon as possible.

In most cases, F-REITs buy farmland from local farmers leaving the farm, and then lease the same land to other local farmers who have a strong operating history and strive to expand agricultural production. Lease is an economic category originally associated with the phenomenon of income derived from the ownership of natural factors (Milanović, Cvijanović, 2009). The two basic types of lease that F-REITs receive as land owners are cash lease and share lease. Cash lease means that the lessee pays a fixed amount of money to the land owner, while in the case of share lease, the land owner receives a fixed share in the realized production. In the case of cash lease, F-REIT, as the land owner, is not exposed to market risks and risks of production, while with share lease F-REIT shares the commodity risk / return directly.

In addition to numerous benefits and positive sides, investing money in F-REITs has its negative sides. The key shortcomings of investing free cash in F-REITs in relation to direct purchase of farmland are:

- Investors bear the entire investment risk, but they do not get the full return due to management fee, and often the front-end fee and back-end fee charged by trusts,

- The choice of specific investment is beyond the control of investors - the decision on each individual investment in specific farmland is made by the portfolio manager of the trust,

- Lower profitability of investment due to a high degree of diversification of investment that implies the achievement of average return.

It should be kept in mind that the obligation of F-REIT to pay at least $90 \%$ of taxable income during the year to its shareholders, although it allows the exemption from income tax and provides attractive investment in these trusts, at the same time indicates a modest, unallocated part of profit that is used for reinvestment and expansion of 
trust activities. The above speaks of the modest possibilities of self-financing the growth of these trusts.

\section{Conclusion}

For fear of losing land and jobs, local farmers and local population through history have often resisted the increased investment of institutional investors in farmland. They were afraid that losing their land would make them lose not only the source of income, but also local features, identity, and culture. That the fear of the local community was unjustified and that by far the largest part of farmland is still privately owned by farmers is confirmed by the view that the share of farmland owned by institutional investors, according to de Laperouse (2016), is today only about $0.5 \%$ of the total value of farmland on a global scale. Local farmers no longer perceive institutional investors as a threat to their business, culture, and tradition, but as a source of stable and longterm capital that contributes to the development of agriculture.

The above should be a source of opportunity to develop a global farmland real estate investment trust industry. With the establishment and development of F-REITs, farmland would, as a new asset class, become available to investors with a modest amount of free capital, insufficient for the purchase of farmland, but sufficient for the purchase of one or more stocks of F-REITs. The development of F-REITs would improve liquidity and marketability of farmland market. The funds of these institutional investors, in addition to financing growth and development of the agricultural sector, would ultimately contribute to the reduction of global poverty and the sustainable development of the world economy and society.

The establishment and development of the F-REIT industry would be particularly useful for developing countries that are in the long-term transition period. The potential benefits F-REITs could achieve by investing in farmland on the territory of these countries are: 1) organization of modern agricultural production, 2) putting into operation of farmland that has been out of use for years, 3) privatization of underperforming state-owned agricultural enterprises, 4) attracting large world producers of agricultural products to whom land is leased out, 5) opening new and well-paid jobs for the local population, 6) investing in infrastructure, and so on.

Although the prices of agricultural products have fallen in recent years, among other things, as a result of low oil prices and, hence, low production costs, the rising demand for food worldwide promises significant and stable return to investors in farmland, with simultaneous protection against inflation. In the following years, farmland return is expected to grow on the basis of: 1) the expected increase in the value of farmland due to global land rush, 2) the expected increase in agricultural commodity prices due to the rising global demand for food, and 3) the expected increase in agricultural productivity due to the application of modern techniques and technology and modern chemization and mechanization methods. Considering the expected growth of farmland return, the accelerated growth and development of the F-REIT industry is to be expected, primarily in the most developed countries of the world, and then in developing countries. 
The above views have been presented in order to point out the importance of farmland as a new asset class, and F-REITs as new farmland investment vehicles. Future research will aim at enriching literature in this field, and will focus on empirical testing of the effect of including farmland in the portfolio, measuring the performance of the F-REITs portfolio, and comparing the achieved performance with the average market performance of the same and different asset classes.

\section{Acknowledgements}

The paper is part of the research at the project III-46006 "Sustainable agriculture and rural development in terms of the Republic of Serbia strategic goals realization within the Danube region", financed by the Ministry of Education, Science and Technological Development of the Republic of Serbia.

\section{Conflict of interests}

The authors declare no conflict of interest.

\section{References}

1. Coleman, L. (2007). Applying modern portfolio techniques to agriculture. The Finsia Journal of Applied Finance, 4, 16-21 (available at: https://www.finsia. com/docs/default-source/jassa-new/jassa-2007/4_2007_modern_portfolio. pdf?sfvrsn=8cd2de93_6).

2. de Laperouse, P. (2016). Agriculture: ANew Asset Class Presents Opportunities for Institutional Investors. Global AgInvesting (available at: http://www. globalaginvesting.com/wp-content/uploads/2016/06/GAI_White-Paper Institutional-Investment-in-Agriculture-1.pdf).

3. Đurić, K., \& Njegovan, Z. (2016). Sustainable Intensification in Agriculture as a Factor of Achieving Food Security. Economics of Agriculture, 63(3), 929-942 (available at: http://bsaae.bg.ac.rs/images/Ekonomika\%20kompletna/2016/ EP\%203\%202016lq.pdf).

4. Fairbairn, M. (2014). "Just another asset class"?: Neoliberalism, finance, and the construction of farmland investment. In S. A. Wolf \& A. Bonanno (Eds.), The Neoliberal Regime in the Agri-Food Sector: Crisis, Resilience, and Restructuring (pp. 245-262). Routledge, New York, U.S. (available at: https://www.taylorfrancis.com/books/e/9781136667060/chapters/10.4324\% 2F9780203583111-21)

5. Farmland Partners (2016). Annual Report to Stockholders (available at: http:// www.annualreports.com/HostedData/AnnualReports/PDF/NYSE_FPI 2016.pdf).

6. FBR \& Co (2016). Financial Services/Real Estate: Specialty REITs (available at: $\quad$ https://static1.squarespace.com/static/570c2f74c2ea513f7d9ada16/t/5 7d7dde7893fc09c3373a11a/1473764840289/593040a0-03cd-4589-a48689ea4a32d721.pdf). 
7. Gladstone Land (2016). Annual Report (available at: http://files.shareholder. com/downloads/AMDA-2M064C/5730768933x0x935759/6F518A82-A1314F6E-960E-C2F08144BCF5/GladstoneLAND 2016AR.pdf).

8. Hennings E., Sherrick, B. J., \& Barry, P. J. (2005). Portfolio Diversification Using Farmland Investments. American Agricultural Economics Association Annual Meeting, Providence, Rhode Island, U.S. (available at: http:// ageconsearch.umn.edu/bitstream/19273/1/sp05he05.pdf).

9. Johnson, M., Malcolm, B., \& O'Connor, I. (2006). The Role of Agribusiness Assets in Investment Portfolios. Australasian Agribusiness Review, 14(11), 1-35 (available at: http://ageconsearch.umn.edu/record/126096/files/Johnson Malcolm O Connor.pdf).

10. Kaplan, H. M. (1985). Farmland as a portfolio investment. The Journal of Portfolio Management, 11(2), 73-78. https://doi.org/10.3905/jpm.1985.408992

11. Koeninger, J. (2017). History of Institutional Farmland Investment. HighQuest Partners, Danvers, Massachusetts, U.S. (available at: http://www. globalaginvesting.com/wp-content/uploads/2017/04/Farmland Investment History_Koeninger_HQP.pdf).

12. Lins, D. A., Sherrick, B. J., \& Venigalla, A. (1992). Institutional Portfolios: Diversification through Farmland Investment. Real Estate Economics, 20(4), 549-571. https://doi.org/10.1111/1540-6229.00596

13. Milanović, M., \& Cvijanović, D. (2009). Problems and Possibilities of Economic Evaluation of Agro-Ecological Resources. Economics of Agriculture, 55, 5-30. [inSerbian: Милановић, М., \& Цвијановић, Д.(2009). Проблеми одрживости и могућности економског вредновања агроеколошких ресурса] (available at: http://bsaae.bg.ac.rs/images/Ekonomika\%20kompletna/2009/Tematski\%20 broj\%20-\%202009.pdf).

14. Nartea, G., \& Eves, C. (2010). Role of farm real estate in a globally diversified asset portfolio. Journal of Property Investment \& Finance, 28(3), 198-220 (available at: http://eprints.qut.edu.au/33283/1/c33283.pdf).

15. Painter, M. J. (2013a). North American Farmland Investment Performance Assessment Using E-V Analysis, CAPM and Value at Risk. 19th International Farm Management Congress, SGGW, Warsaw, Poland (available at: http:// ifmaonline.org/wp-content/uploads/2014/08/13_Painter_P9-18v3.pdf).

16. Painter, M. J. (2013b). Gold, black gold, and farmland: should they all be part of your investment portfolio? International Journal of Agricultural Management, 2(2), 100-112. https://doi.org/10.5836/ijam/2013-02-05

17. Robaton, A. (2015). Farming REITs. REIT Magazine, Washington, U.S. (available at: https://www.reit.com/news/reit-magazine/january-february-2015/ farming-reits 